\title{
A Perspective on Conflict and Performance of International Construction Projects
}

\author{
"Eyad Zouher Al-Sibai ${ }^{1} \&$ Ali Mohammed Alashwal ${ }^{2}$ \\ ${ }^{12}$ Department of Quantity Surveying, Faculty of Built Environment, University of Malaya, Kuala \\ Lumpur \\ *arch.eyad@gmail.com
}

\begin{abstract}
Conflict is unavoidable in any construction project and may influence its performance. International construction projects involve people from different backgrounds, professions, and ethnic groups. This milieu may become a trigger for sever conflict. The purpose of this paper is to highlight the influence of conflict on the performance of international construction projects. Conflict and project performance were measured using several variables synthesized from the relevant literature. Conflict variables were categorized into two types: internal and external conflicts. Subsequently, a questionnaire survey was developed and sent to individuals working in Malaysian contractor companies, who have experience in overseas projects. All together, 161 questionnaires were collected. Data analysis using linear regression indicated the influence of four variables of the internal conflict on project performance. It is evident that the external conflict may not be significant in the context of international construction project. Thus, it is important to pay greater attention to the internal-related variables of conflict to enhance project performance.
\end{abstract}

Keywords: international construction projects, performance, internal conflict

\section{INTRODUCTION}

Conflict is a clash between hostile or opposing elements or ideas (Cleland, 1995). Conflict is incompatible activities which occur when the behavior of one person is interfering or obstructing the actions of another (Deutsch, 1977). Champoux (2010) provided a wide-range definition of conflict including doubt or questioning, opposition, incompatible behavior, controversy or antagonistic interaction and disputes. On the other hand, Kumaraswamy and Yogeswaran (1998) pointed out that rejection is not accepted when a claim or assertion is made by one party and is rejected by the other party. This shows that disagreements are likely taking place when the conflicting parties show a controversy action or an argument.

Project performance is commonly determined by four factors: project budget, project schedule, quality, and client satisfaction (Ozorhon et al., 2007). Conflict during construction works may affect one or more of these factors. In addition, conflicts may cause interruptions and occasionally suspension of the whole construction works. The influence of conflict on the performance of construction organizations was 
highlighted in several studies (Deutsch, 1969; Duarte \& Davies, 2003; Dyer \& Song, 1998; Gobeli et al., 1998; Lam \& Chin, 2005; Rahim, 2010; Thomas, 1992; Weinrauch \& Anderson, 1982).

The aim of this paper is to investigate the influence of conflict in the context of international construction projects. In particular, this paper attempts to achieve two objectives. The first objective is to identify the measurement variables of conflict in construction project. The second objective is to determine the influence of conflict variables on the performance of international construction projects. Following this introduction, literature review synthesizes the relevant literature to identify conflict sources and variables and discuss their influence on construction project performance. The development of a theoretical framework of two types of conflict, namely, internal and external and their relationship with project performance is shown after that.

\section{SOURCES OF CONFLICT IN CONSTRUCTION PROJECTS}

Thamhain and Wilemon (1975) identified seven major sources that create conflicts, namely: project priorities, administrative procedures, technical opinions and performance, trade-off manpower resources, cost, schedules, and personality. There are also other sources of conflicts which are classified in different ways for the different working environments such as: cultural differences, religious differences, military conflicts, economic conflict, and traffic conflict (Jia et al., 2011).

Many researchers have identified various root causes and variables of conflict in construction organizations. For example, Williamson (1979) acknowledged behavioral problems, contractual problems, and technical problems due to uncertainty and low experience as three main root reasons of conflicts. In addition, Hohns (1979) indicated five primary sources of conflicts in construction project, which are: existence of errors, defects or omissions in the contract documents, failure to count the cost at the commencement of the project, change of conditions, and consumer reaction and people involved. Moreover, Kumaraswamy and Yogeswaran (1998) identified that contractual matters, including variation, extension of time, payment, quality of technical specifications, availability of information, administration and management, unrealistic client expectation and determination are mainly the sources of construction disputes. Fenn et al. (1997) identified other causes of conflict including deficient management, clarity and completeness, poor communications, failure to appoint a project manager, discrepancies or ambiguities in contract documents, inadequate tracing mechanisms for request of information, failure to respond in timely manner, supervision and coordination efforts on the part of the project, lowest price mentality in engagement of contractors and designers, the absence of team spirit among the participants, and lack of constructability.

According to Hall (2002), lack of communication is the main causes of dispute and conflict, which basically causes many problems such as failure to understand consultants' responsibilities, late information delivery and cumbersome approach to request for information, oversights of design and specification, and errors or omissions resulting from uncoordinated and incomplete design, drawings and specifications. Lastly, Thompson et al. (2000) mentioned the factors pertaining to construction conflict including limited communication, distrust, misinterpretations of contracts, uncertainties of role and responsibilities, and imbalance in risk allocations.

\section{IMPLICATIONS OF CONFLICT ON CONSTRUCTION ORGANIZATIONS}

Panteli and Sockalingam (2005) compiled the negative implications of conflict on team and organizational function as the following: promote inefficiency and ineffectiveness, lead to a loss of 
perspective regarding the task, inhibit individuals' cognitive functioning in assessing new information provided, processing complex information, and encourage stereotype listening and induce the freezing out of iconoclasts from important discussions. In addition, Panteli and Sockalingam (2005) stated that trust and conflict are inherent issues of any organizational arrangement and central for knowledge sharing. They mentioned that the organizational conflict literature has identified three common forms of conflict: relationship conflict, task or cognitive conflict, and process conflict. These have a strong interrelationship among each other as the scholars stressed. Table 1 shows some studies that highlighted the negative influence of conflict on different areas in construction projects and organizations.

Conflict, if managed properly, may have a positive impact on organization because it encourages searching for best alternatives. However, based on the previous discussion, conflict has been regarded as a destructive factor that has influence on team, organization, and inter-organization (Panteli \& Sockalingam, 2005).

Table 1: The influence of conflict on construction project performance

\begin{tabular}{|l|l|}
\hline Influence & References \\
\hline $\begin{array}{l}\text { Construction conflicts can affect: Cost, scheduling, } \\
\text { communication, resource allocation, and interpersonal } \\
\text { relationships. }\end{array}$ & $\begin{array}{l}\text { (Acharya et al., 2006; Cheung } \\
\text { \& Chuah, 1999) }\end{array}$ \\
\hline $\begin{array}{l}\text { Internal conflicts can affect project performance through } \\
\text { disputes among participants such as owner, contractor, } \\
\text { designer, and consultant. }\end{array}$ & $\begin{array}{l}\text { (Awakul \& Ogunlana, 2002; } \\
\text { Mahato \& Ogunlana, 2011) }\end{array}$ \\
\hline $\begin{array}{l}\text { Interface conflicts can occur between the construction project } \\
\text { and groups outside the project, such as interruptions/protests } \\
\text { by local people, labor disputes/union strikes, market inflation, and } \\
\text { public disorder. These conflicts can disrupt the administrative and } \\
\text { production processes, increase production costs, and lead to } \\
\text { termination of the construction project relationship prior to } \\
\text { project completion. }\end{array}$ & (Vaaland, 2004) \\
\hline $\begin{array}{l}\text { Construction project performance can be affected by: Cultural } \\
\text { differences, lack of adequate project management, and the } \\
\text { inherent structure of conflicting interests in a project. }\end{array}$ & (Al-Sedairy, 1994) \\
\hline
\end{tabular}

\section{FRAMEWORK OF CONFLICT AND PROJECT PERFORMANCE}

The literature review indicated a negative relationship between conflict and project performance. This paper attempts to develop a framework of this relationship so it can be tested empirically in international construction projects. The framework requires identifying the indicators of conflict and project performance. Previous studies have provided several indicators to measure conflict, which can be categorized into internal and external or interface variables. Conflict and project performance variables and their sources are presented in Table 2. These variable can be compiled into a questionnaire survey and tested in a pilot study for reliability and functionality (Creswell, 2009). 
Table 2: Sources of conflict and project performance variables

\begin{tabular}{|c|c|}
\hline Factors \& Variables Items & References \\
\hline \multicolumn{2}{|l|}{ 1. Internal Conflicts: } \\
\hline $\begin{array}{l}\text { Communication, Resource allocation, Scheduling, Managerial and } \\
\text { administrative procedures, Goal or priority definition, and Reward } \\
\text { structure / performance appraisal or measurement }\end{array}$ & (Kezsbom, 1992) \\
\hline $\begin{array}{l}\text { Personality and interpersonal relations, Politics, Leadership, Ambiguous } \\
\text { roles/structure, Costs, Technical opinion, Unresolved prior conflict, } \\
\text { Cultural differences, Religious differences, Military conflicts, Economic } \\
\text { conflict, and Traffic conflict. }\end{array}$ & (Jia et al., 2011) \\
\hline $\begin{array}{l}\text { Client, Designer, Contractor, Consultant and Various suppliers who } \\
\text { provide labor, materials and equipment }\end{array}$ & (Meng, 2012) \\
\hline $\begin{array}{l}\text { Social conflict, Cultural/religious differences, Poor international } \\
\text { relations, Instability of political condition, Immaturity of legal system, } \\
\text { Poor attitude towards foreign companies, Poor macroeconomic } \\
\text { conditions, Poor experience in the country, and, Contract clauses about } \\
\text { country risk, Technical risk, Managerial risk, Resource risk, Productivity } \\
\text { risk, Design risk, Payment risk, Client risk, and Subcontractor risk }\end{array}$ & (Dikmen et al., 2007) \\
\hline \multicolumn{2}{|l|}{ 2. External / Interface Conflicts: } \\
\hline $\begin{array}{l}\text { Political stability, Macroeconomic condition, Strength of legal system, } \\
\text { Budget, Schedule, Quality, Client satisfaction, Availability of resources, } \\
\text { Tolerance/flexibilities of the client, Completeness of design and contract, } \\
\text { Impact of external/environmental factors, Political risk, Social risk, } \\
\text { Production risk, Operational risks, Regulation risks, Environmental risks } \\
\text { (internal and external), Legal issues, and Cultural issues. }\end{array}$ & (Ozorhon et al., 2007) \\
\hline \multicolumn{2}{|l|}{ 3. Project Performance: } \\
\hline $\begin{array}{l}\text { Time and cost overruns, Low productivity, Poor quality, and Inadequate } \\
\text { customer satisfaction }\end{array}$ & $\begin{array}{l}\text { (Chan \& Raymond, } \\
\text { 2003) }\end{array}$ \\
\hline $\begin{array}{l}\text { Project budget, Project schedule, Quality, Client satisfaction, Political } \\
\text { stability, Macroeconomic conditions, Strength of legal system, } \\
\text { Completeness of payments by the client, and Relations with other project } \\
\text { participants. }\end{array}$ & (Ozorhon et al., 2007) \\
\hline $\begin{array}{l}\text { Poor contractor management, Poor construction design, Poor labor } \\
\text { performance, Poor technical ability, Material procurement problems, } \\
\text { Lack of construction equipment, and etc., Adverse weather conditions, } \\
\text { Unforeseen site conditions, Market fluctuation, and Regulatory changes. }\end{array}$ & (Meng, 2012) \\
\hline
\end{tabular}

It is postulated that conflict (indicated by internal and interface conflicts) has a negative influence on the performance of international construction project. Figure 1 depicts this statement. This study will attempt to determine which variable of conflict has a significant relationship with project performance. The research framework illustrates two hypotheses as follows: 
Hypothesis 1: Internal conflict has a negative influence on the performance of international construction projects.

Hypothesis 2: Interface/external conflict has a negative influence on the performance of international construction projects in host countries.

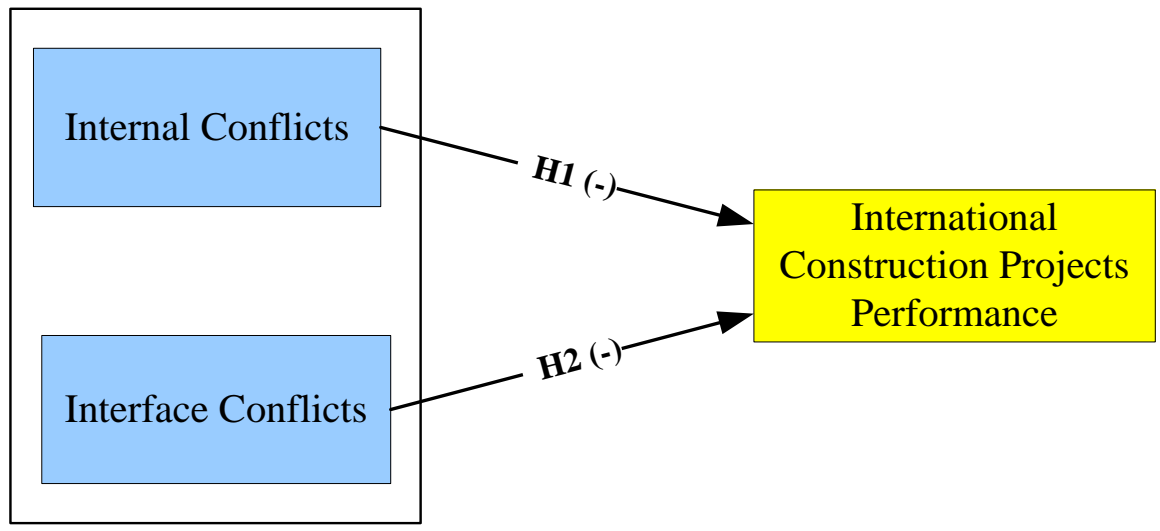

Figure 1: Research framework

\section{METHODOLOGY}

\section{MEASUREMENT INSTRUMENT}

A quantitative approach using questionnaire survey (Creswell, 2009) was used to test the proposed framework. The variables of conflict and project performance, which identified from the literature and summarized in Table 2, were used to develop the measurement instrument. Measurement variables can be incorporated and operationalized into the instrument after defining the appropriate measurement scale (Babbie, 2008). Table A1 shows the compiled variables in the questionnaire instrument, which were measured using a 5-point Likert scale.

Table A1: Measurement variables of the questionnaire survey

\begin{tabular}{|l|}
\hline 1. Conflict Variables \\
\hline 1.1 Lack of staff communication during project process \\
\hline 1.2 Lack of professional technical opinion \\
\hline 1.3 Lack of contractor experience \\
\hline 1.4 Lack of consultant experience \\
\hline 1.5 Lack of follow-up \\
\hline 1.6 Lack of appropriate skills \\
\hline 1.7 Lack of staff knowledge \\
\hline 1.8 Lack of manager feedback \\
\hline 1.9 Insufficient of site supervision \\
\hline 1.10 Misplace of resources allocation \\
\hline
\end{tabular}




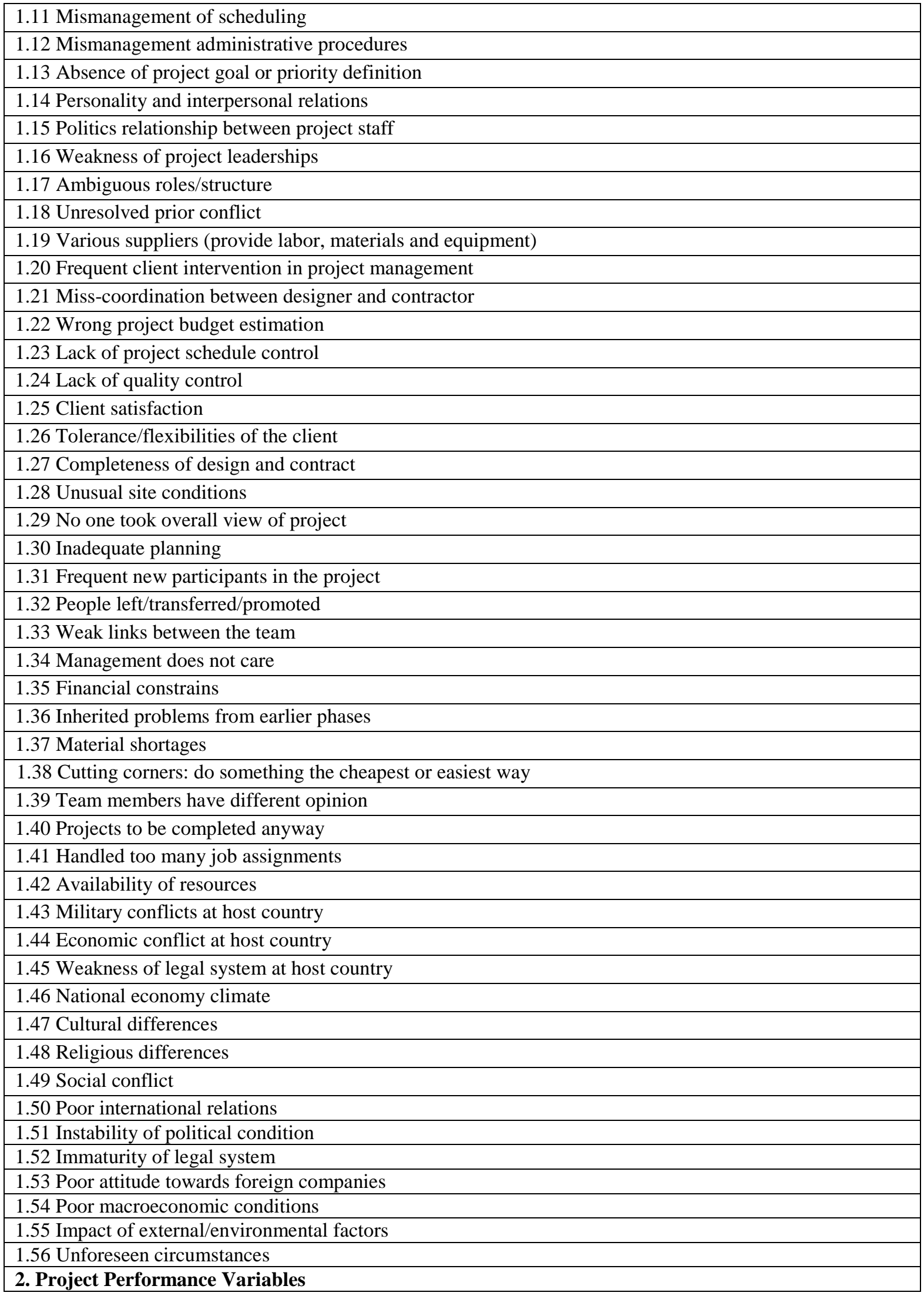




\begin{tabular}{|l|}
\hline 2.1 Time overrun \\
\hline 2.2 Cost overrun \\
\hline 2.3 Poor quality productivity \\
\hline 2.4 Low productivity \\
\hline 2.5 Inadequate customer satisfaction \\
\hline 2.6 Mismanagement of project schedule \\
\hline 2.7 Use poor materials quality \\
\hline 2.8 Bad political stability at the host country \\
\hline 2.9 Bad macroeconomic conditions \\
\hline 2.10 Weakness of legal system \\
\hline 2.11 Completeness of payments by the client \\
\hline 2.12 Bad relations among other project participants \\
\hline 2.13 Poor contractor management \\
\hline 2.14 Poor construction method \\
\hline 2.15 Poor labour performance \\
\hline 2.16 Poor technical ability \\
\hline 2.17 Material procurement problems \\
\hline 2.18 Lack of construction equipment \\
\hline
\end{tabular}

\section{SAMPLING AND DATA COLLECTION}

This study targeted professionals in Malaysia who have experience in overseas construction projects. It was difficult to determine the exact number of individuals who have been involving in overseas construction projects. Therefore, professionals and consultants working in Malaysian international construction firms were approached to answer the questionnaire. Contractor companies that have been conducting projects overseas were set as the population of this study. While conducting this research, there were 90 international contracting firms registered with the Construction Industry Development Board (CIDB) Malaysia (CIDB, 2011). A self-administered survey used and targeted individuals with experience in international construction projects in these companies.

\section{DATA ANALYSIS METHOD}

According to Seber and Lee (2012), regression attempts to model the relationship between two variables by fitting a linear equation to observed data. One variable is considered an explanatory variable, and the other is a dependent variable. A linear regression model attempts to explain the relationship between two or more variables using a straight line. The purpose of this analysis is to explore if there is a causal relationship between conflict and the performance of international projects. The analysis will provide an indication of the influence of conflict as independent variable on project performance as the outcome variable.

\section{RESULTS AND DISCUSSION}




\section{RESPONDENTS}

All together, 161 valid questionnaire forms were collected from individuals in the approached companies. Most of the respondents aged between 30 to 39 (41\%) while some are aged between 50 to 59 (9.3\%). Most respondents had Bachelor Degree (61\%), Master Degree (34\%), and Others (5\%). Professions of the respondents are Civil and Structural Engineering (60\%), Quantity Surveying (18\%), Architecture (8\%) and other professions. Experience of the respondents in construction is mostly between 6 to 10 years. Lastly, most respondents were Project Managers (32\%), followed by Consultants (13\%), Site Engineers (9\%), Top Managers (8\%), Others (25\%) and missing data (13\%).

\section{RESULTS OF LINEAR REGRESSION}

The results of the analysis using Stepwise method of regression analysis determined the variables that have significant correlations with the dependent variable PERFORM (performance of international construction projects). Four variables, namely, cutting corners, management does not care, religious differences, and inherited problems from earlier phases, influence PERFORM as shown in Table 3. The results of the four models of regression are significant and showed moderate influence on project performance supported by R-square value ( 0.203 to 0.336 ). This results is further supported by the results of analysis of variance (ANOVA), which examines whether there is a difference in the influence on performance between the four models (refer to Table 4).

Table 3: Results of linear regression

\begin{tabular}{|c|c|c|c|c|c|c|c|c|c|}
\hline \multirow[b]{2}{*}{$\begin{array}{c}\text { Mode } \\
1\end{array}$} & \multirow[b]{2}{*}{$\mathbf{R}$} & \multirow[b]{2}{*}{$\begin{array}{c}\text { R } \\
\text { Squar } \\
\text { e }\end{array}$} & \multirow[b]{2}{*}{$\begin{array}{l}\text { Adjuste } \\
\text { d R } \\
\text { Square }\end{array}$} & \multirow{2}{*}{$\begin{array}{c}\text { Std. } \\
\text { Error of } \\
\text { the } \\
\text { Estimat } \\
\text { e } \\
\end{array}$} & \multicolumn{5}{|c|}{ Change Statistics } \\
\hline & & & & & $\begin{array}{c}\text { R } \\
\text { Square } \\
\text { Chang } \\
\text { e }\end{array}$ & $\begin{array}{c}\text { F } \\
\text { Chang } \\
\text { e }\end{array}$ & $\begin{array}{c}\text { df } \\
1\end{array}$ & df2 & $\begin{array}{c}\text { Sig. F } \\
\text { Chang } \\
\text { e }\end{array}$ \\
\hline 1 & .451 & .203 & .198 & .54689 & .203 & 40.486 & 1 & $\begin{array}{c}15 \\
9\end{array}$ & .000 \\
\hline 2 & .512 & .262 & .252 & .52804 & .059 & 12.560 & 1 & $\begin{array}{c}15 \\
8\end{array}$ & .001 \\
\hline 3 & $\begin{array}{c}.563 \\
\mathrm{c}\end{array}$ & .317 & .304 & .50951 & .055 & 12.700 & 1 & $\begin{array}{c}15 \\
7\end{array}$ & .000 \\
\hline 4 & $\begin{array}{c}.579 \\
\mathrm{~d}\end{array}$ & .336 & .319 & .50403 & .019 & 4.433 & 1 & $\begin{array}{c}15 \\
6\end{array}$ & .037 \\
\hline
\end{tabular}

a. Predictors: (Constant), Cutting corners

b. Predictors: (Constant), Cutting corners, Management does not care

c. Predictors: (Constant), Cutting corners, Management does not care, Religious differences

d. Predictors: (Constant), Cutting corners, Management does not care, Religious differences,

Inherited problems from earlier phases 
Table 4: Results of ANOVA

\begin{tabular}{|c|c|c|c|c|c|c|}
\hline \multicolumn{2}{|c|}{ Model } & $\begin{array}{c}\text { Sum of } \\
\text { Squares }\end{array}$ & df & $\begin{array}{c}\text { Mean } \\
\text { Square }\end{array}$ & F & Sig. \\
\hline \multirow{3}{*}{1} & Regression & 12.109 & 1 & 12.109 & 40.486 & $.000^{\mathrm{a}}$ \\
\cline { 2 - 7 } & Residual & 47.556 & 159 & .299 & & \\
\cline { 2 - 8 } & Total & 59.665 & 160 & & & \\
\hline \multirow{3}{*}{2} & Regression & 15.611 & 2 & 7.805 & 27.994 & $.000^{\mathrm{b}}$ \\
\cline { 2 - 8 } & Residual & 44.054 & 158 & .279 & & \\
\cline { 2 - 8 } & Total & 59.665 & 160 & & & \\
\hline \multirow{3}{*}{3} & Regression & 18.908 & 3 & 6.303 & 24.278 & $.000^{\mathrm{c}}$ \\
\cline { 2 - 8 } & Residual & 40.757 & 157 & .260 & & \\
\cline { 2 - 8 } & Total & 59.665 & 160 & & & \\
\hline \multirow{3}{*}{4} & Regression & 20.034 & 4 & 5.009 & 19.715 & $.000^{\mathrm{d}}$ \\
\cline { 2 - 8 } & Residual & 39.631 & 156 & .254 & & \\
\cline { 2 - 8 } & Total & 59.665 & 160 & & & \\
\hline
\end{tabular}

a. Predictors: (Constant), Cutting corners

b. Predictors: (Constant), Cutting corners, Management does not care

c. Predictors: (Constant), Cutting corners, Management does not care, Religious

differences

d. Predictors: (Constant), Cutting corners, Management does not care, Religious

differences, Inherited problems from earlier phases

e. Dependent Variable: PERFORM

This result indicated that internal conflict might have a major influence on the performance of international construction projects. All the four variables of conflict that influence project performance are measuring internal conflict. These are 'cutting corners', 'management does not care', 'religious differences', and 'inherited problems from earlier phases'. This indicates a major influence of internal conflict and, hence, supports the first hypothesis. External conflict may not have an influence on project performance as presumed previously.

Conflict can happen over working methods in international projects. The variable 'cutting corners' indicates the way of performing certain activities using the cheapest or easiest way. This may cause a conflict within the project team with regard to achieving better outcomes in the project. Top management decision to cut corners may lead to conflict that influences project performance. The level of attention and care of top management may also influence project performance. Less attention of the top management may cause frustrated working environment, lower satisfaction of employees, and lack of direction, which all trigger conflict in the project. Unresolved previous conflict can cause stronger conflict later on and impact project performance. Inherited problems from previous phases, such as dispute over project budget, design, or objectives of the project, have an extended influence on the project. An efficient and early resolution of conflicts is very important to ensure constant project team performance.

International construction projects involve various people from different backgrounds, professions, cultures, and religions. The religious difference, as a measure of internal conflict, was found to influence 
project performance. This type of conflict, if happen, is expected to cause a negative working environment and will be difficult to resolve.

External conflict variables, such as military conflict, economic conflict at host country, poor international relations and others, may have no direct influence on the performance of international construction projects. The reason for this low influence could be that the external conflict factors are already secured and identified before undertaking a project. Contractor companies may conduct sufficient initial studies to identify various risks in the host country before making a decision to venture for international projects.

The results of this paper indicated that construction projects, regardless of the context, are facing the same factors of conflict. A project manager in international construction project shall pay a greater attention to internal factors that cause conflict in his or her project to ensure better project performance and outcome.

\section{CONCLUSION}

This study identified conflict variables that influence the performance of international construction projects. The results of data analysis highlighted four variables, namely: 'cutting corners: do something the cheapest or easiest way', 'management does not care', 'religious differences', and 'inherited problems from earlier phases'. In addition, the results proposed that internal conflict, unlike external conflict, has a main influence on the performance of international construction projects. These results serve as an indication of the relationship between conflict and project performance. A future study will conduct further analysis to identify the conflict components in international construction projects context using Factor Analysis. A subsequent analysis will use Structural Equation Modelling (SEM) to determine the exact influence of conflict components on project performance.

\section{ACKNOWLEDGEMENT}

The authors would like to thank the anonymous reviewers for taking the efforts to evaluate and comment on earlier versions of this paper.

\section{REFERENCES}

Acharya, N. K., Dai Lee, Y., \& Im, H. M. (2006). Conflicting factors in construction projects: Korean perspective. Engineering, Construction and Architectural Management, 13(6), 543-566.

Al-Sedairy, S. T. (1994). Management of conflict: Public-sector construction in Saudi Arabia. International Journal of Project Management, 12(3), 143-151.

Awakul, P., \& Ogunlana, S. O. (2002). The effect of attitudinal differences on interface conflicts in large scale construction projects: A case study. Construction Management \& Economics, 20(4), 365377.

Babbie, E. (2008). The basics of social research (4th ed.). Belmont: Thomson Wadsworth.

Champoux, J. E. (2010). Organizational behavior: Integrating individuals, groups and organizations ( $4^{\text {th }}$ ed.). New York: Routledge.

Chan, E., \& Raymond, Y. (2003). Cultural considerations in international construction contracts. Journal of Construction Engineering and Management, 129(4), 375-381.

Cheung, C. C., \& Chuah, K. (1999). Conflict management styles in Hong Kong industries. International Journal of Project Management, 17(6), 393-399. 
CIDB. (2011). Buletin statistik pembinaan suku tahunan - 2011 (Construction Quarterly Statistical Bulletin) (Vol. Suku 3). CIDB.

Cleland, D. (1995). Project management: Strategic design and implementation (International ed.). Singapore: McGraw-Hill.

Creswell, J. W. (2009). Research design: Qualitative, quantitative, and mixed methods approaches (3rd ed.). California: Sage Publication.

Deutsch, M. (1969). Conflicts: Productive and destructive. Journal of Social Issues, 25(1), 7-42.

Deutsch, M. (1977). The resolution of conflict: Constructive and destructive processes, Yale University Press.

Dikmen, I., Birgonul, M. T., \& Han, S. (2007). Using fuzzy risk assessment to rate cost overrun risk in international construction projects. International Journal of Project Management, 25(5), 494505.

Duarte, M., \& Davies, G. (2003). Testing the conflict-performance assumption in business-to-business relationships. Industrial Marketing Management, 32(2), 91-99.

Dyer, B., \& Song, X. M. (1998). Innovation strategy and sanctioned conflict: A new edge in innovation? Journal of Product Innovation Management, 15(6), 505-519.

Fenn, P., Lowe, D., \& Speck, C. (1997). Conflict and dispute in construction. Construction Management \& Economics, 15(6), 513-518.

Gobeli, D. H., Koenig, H. F., \& Bechinger, I. (1998). Managing conflict in software development teams: A multilevel analysis. Journal of Product Innovation Management, 15(5), 423-435.

Hall, J. (2002). Ineffective communication: Common causes of construction disputes. Alliance's Advisory Council Legal Notes, 13(2).

Hohns, H. M. (1979). Preventing and solving construction contract disputes. New York : Van Nostrand Reinhold.

Jia, G., Yang, F., Wang, G., Hong, B., \& You, R. (2011). A study of mega project from a perspective of social conflict theory. International Journal of Project Management, 29(7), 817-827.

Kezsbom, D. S. (1992). Re-opening Pandora's box: Sources of project conflict in the '90's. Industrial Engineering, 24(5), 54-59.

Kumaraswamy, M., \& Yogeswaran, K. (1998). Significant sources of construction claims. International Construction Law Review, 15(1), 144-160.

Lam, P. K., \& Chin, K. S. (2005). Identifying and prioritizing critical success factors for conflict management in collaborative new product development. Industrial Marketing Management, 34(8), 761-772.

Mahato, B. K., \& Ogunlana, S. (2011). Conflict dynamics in a dam construction project: A case study. Built Environment Project and Asset Management, 1(2), 6-6.

Meng, X. (2012). The effect of relationship management on project performance in construction. International Journal of Project Management, 30(2), 188-198.

Ozorhon, B., Arditi, D., Dikmen, I., \& Birgonul, M. T. (2007). Effect of host country and project conditions in international construction joint ventures. International Journal of Project Management, 25(8), 799-806.

Panteli, N., \& Sockalingam, S. (2005). Trust and conflict within virtual inter-organizational alliances: A framework for facilitating knowledge sharing. Decision Support Systems, 39 (4), 599-617.

Rahim, M. A. (2010). Managing conflict in organizations. New Jersey: Transaction Pub.

Seber, G. A., \& Lee, A. J. (2012). Linear regression analysis. New Jersey: John Wiley \& Sons.

Thamhain, H. J., \& Wilemon, D. L. (1975). Conflict management in project life-cycle. Sloan Management Review, 16(3), 31-49. 
Thomas, K. W. (1992). Conflict and negotiation processes in organizations. In M. D. Dunnette \& L. M. Hough (Eds.), Handbook of Industrial and Organizational Psychology (Vol. 3). California: Consulting Psychological Press.

Thompson, R. M., Vorster, M. C., \& Groton, J. P. (2000). Innovations to manage disputes: DRB and NEC. Journal of Management in Engineering, 16(5), 51-59.

Vaaland, T. I. (2004). Improving project collaboration: Start with the conflicts. International Journal of Project Management, 22(6), 447-454.

Weinrauch, D. J., \& Anderson, R. (1982). Conflicts between engineering and marketing units. Industrial Marketing Management, 11(4), 291-301.

Williamson, O. E. (1979). Transaction-cost economics: The governance of contractual relations. Journal of Law and Economics, 22(2), 233-261. 